\title{
VÁROSPUSZTULÁS ÉS FELÚJÍTÁS BUDAPESTEN
}

\author{
Lichtenberger, E. - Cséfalvay Z. - Paal, M. (1995) \\ Magyar Trendkutató Központ, Budapest
}

A kötet szerzöi sajátos szempontból, a bérlakásállomány pusztulásán, rehabilitációján és privatizációján keresztül vizsgálják a fövárosban az 1990-es években lejátszódott térbeli folyamatokat. A szerzők egyik érdeme, hogy az angolszász szakirodalomban használatos szakkifejezéseket is felhasználva világos, pontos definíciókat alkottak a várospusztulásról és felújitásról, illetve az ezekhez kapcsolódó fogalmakról.

A munka alapja a budapesti rehabilitációs övezet (V., VI.,VII., VIII., IX. kerület) teljes bérlakásállományára kiterjedő empirikus vizsgálat, melynek eredményeit történeti és szociológiai összefüggésben elemezték. A Budapest térbeli társadalmi és funkçionális fejlödésével foglalkozó szociológiai (Szelényi I., Csanádi G, Ladányi J.) és geográfiai (Probáld F., Beluszky P., Cséfalvay Z., Pomázi I., Kovács Z.) munkák a bérlakások slumosodásának, privatizációjának, funkcióváltásának kérdését a térbeli folyamatok egyik elemeként érintették. A „Várospusztulás és felújítás Budapesten" címü mü ezért fontos elméleti és módszertani adalék mindkét tudományterület mủvelöi számára.

Nem hanyagolható el a munka gyakorlati jelentősége sem: az empirikus kutatások segítségével értékelhető az elöző korszak városfelújítási gyakorlata, felmérhető a bérlakásállomány állapota, megbecsülhetőek a felújítás költségei Budapesten és a vidéki városokban.
A szerzők közel 220 oldalon, szigorủ logikai rendben foglalják össze eredményeiket. Az első lépés - és fejezet - a várospusztulás és felújitás fogalmának definiálása, továbbá e folyamatok általános modelljének felállítása (Lichtenberger, E.), melyet Budapestre is alkalmaznak. A fejlődés föbb szakaszai: a 60-as években nekilendülő lakásépités, amely a 70-es évek közepén éri el csúcspontját és megtorpan a 80-as évek közepén; illetve az 1985 körül elinduló felújítási folyamat, amely csak négy-öt évig tart. A rendszerváltással az előző ciklus félbeszakadt és a megújitás 1990 után, az új szakaszban még nem indult el.

Cséfalvay $Z$. a fenti modellre építkezve elemzi az 1945 és 1989 közötti idöszak fejlödését. Ennek legfontosabb tanulsága a bérlakásállomány szempontjából, hogy a koncepció nélkül történö szigetszerú rehabilitáció, melyet az állam irányított, ám rosszul koordinált, nem vezetett a kivánt eredményre, mert folytatódott a középosztálybeliek elvándorlása e negyedekből, ugyanakkor a felújított „szigetek” a második gazdaság színterévé váltak, tehetős rétegek foglalták el a felújított lakásokat (,szocialista dzsentrifikáció”).

A 90-es években elkezdődött új ciklusban a szerzök szerint (Cséfalvay Z.-Lichtenberger, E.) két alapvető változás határozta meg a bérlakások sorsát a szerzők szerint: új „főszereplők” megjelenése a 
piacon (a tulajdonossá vált kerületek és a növekvő kereslettel jelentkezö külső beruházók) és a piaci viszonyok meghatározóvá válása a szereplők viszonyában. Ilyen feltételek mellett kezdódött meg a bérlakások privatizációja, melynek eddigi legfontosabb eredménye eddig a kerületek között és az azokon belül meginduló térbeli differenciálódás a privatizáció és a felújítás ütemében (utóbbi esetében a cityhez közel fekvő városrészek elönyére).

A várospusztulási jelenségeket és a felújítás folyamatának hatásait a munka „központi" része, a leghosszabb fejezet tartalmazza (Lichtenberger, E.). Alapja a Michaela Paal által végzett felmérés a rehabilitációs övben házanként, lakótömbönként és a klasszikus társadalmi-építészeti hierarchia szerint. Színes melléklet és több mint másfél tucatnyi ábra, térkép mutatja be lakótömbök, kerületek példáján az említett folyamatokat. A szocialista felújitási gyakorlat eredményeit összegezve a szerző megállapítja, hogy arra a szigetszerủség és befejezetlenség jellemzö, és ami mindezek hátterében áll: a programok felaprózódása, a pénzügyi források és az irányítás koordinációjának hiánya. Ennek következménye a bérlakásállomány halmozódó pusztulása lett.

A 90-es évek elején elinduló privatizáció az állományon belül meglevő külőnbségeket tovább erősítette, a felújitott „szigetek” és környékük felértékelödött - amit az ingatlanárak alakulása is bizonyít -, és a privatizáció itt gyorsan lezajlott. Ugyanakkor a leromlott lakónegyedek slumosodása tovább folytatódik, a magánosítás is megtorpant, elsősorban az V. és VIII. kerület kiterjedt területein. Az irodahelyiségek élénkülö piacán a rehabilitációs övezet cityhez közeli részei fontos tartalék területeknek bizonyultak. A city expanziója és a slumosodás a felmérés szerint tehát párhuzamosan, egymás töszomszédságában zajlik.

A könyv talán legkevésbé sikerült fejezete a társadalom térbeliségét taglaló rész. A szerzö (Lichtenberger, E.) elsősorban a bérlakás-privatizáció mutatóin keresztül kísérelte meg felvázolni Budapest funkcionális modelljét. A vizsgálat szintjét a kerületek jelentették, és ennek alapján három sajátos elem emelhetö ki a térszerkezetból: a budai zöldővezet, amely megmaradt „elitnegyednek” és ahol a privatizáció korán lezajlott; a terjeszkedỏ city, ahol a megmaradt lakásállomány erősen leértékelödött; illetve a differenciálódó rehabilitációs övezet.

A többi városrész jóval kisebb hangsúlyt kap az elemzésben, ami nyilván az alkalmazott mutatóknak köszönhető. A társadalmi folyamatok elemzéséhez szükséges szociológiai kategóriák is hiányoznak, a „középosztály” és a „felső osztályok" meghatározása nem elég pontos egy térbeli társadalmi modell megrajzolásához. A szerző inkább csak néhány, a bérlakások privatizációja által érintett városrész mobilitási folyamataira utal, a modell felvázolása nem mondható sikeresnek.

A könyv méltó - és igen érdekes - befejezése Bécs és Budapest bérlakás-problémáinak összevetése, amely alapján fơvárosunk kelet-közép-európai, megkésett fejlödéséből fakadó sajátosságai is kirajzolódnak. Ezek közé tartozik a századfordulón lejátszódott városrobbanás, amely gyenge minöségü, tömeges bérházépítésre ösztönözte a befektetöket, valamint a második világháború után kialakult (kialakított) 
tulajdonviszonyok. Bécs lassúbb, harmonikusabb fejlödése, a rehabilitáció koncepciózus, köz- és magánszektorra alapozott végrehajtása fontos tanulságokkal szolgál a hazai várostervezóknek és -irányítóknak.

Úgy vélem, a fenti tanulságokhoz már csak egy dolgot kell hozzátennünk: hasonló vizsgálatokat Budapest többi kerületében (például a lakótelepeken) és vidéki nagyvárosainkban is szükséges elvégezni, hiszen az összehasonlítás az egyes önkormányzatok gyakorlatában és az intézkedések társadalmi hatásaiban fontos tanulságokkal szolgálna elméleti és gyakorlati szakemberek számára egyaránt.

Nagy Erika

\section{KAZINCBARCIKÄ - ZSÁKUTCA VAGY ÚTELÁGAZÁS}

Síkos T. T. (szerk.) MTA RKK, Budapest, 1995. 174 o.

Az MTA RKK Budapesti Osztálya munkáját dicséri ez a kötet, még akkor is, ha a szerzök között más kutatók nevével is találkozhattunk.

A könyv egy „csinált" város múltját és jelenét tárja fel a szerzók által legfontosabbnak itélt aspektusokból.

A témaválasztás tovább mutat a konkrétan feldolgozott példán, $\mathrm{s}$ általában felveti azt a kérdést, hogy a magyarországi "csinált" városok hogyan, milyen eszközökkel, s mennyiben voltak képesek alkalmazkodni a társadalmi-gazdasági-környezeti válság egyes jelenségeihez. $\mathrm{E}$ városcsoportmak az elmúlt néhány évtized által kijelölt fejlödési pályája mennyiben volt továbbvihetö, $s$ végül a települések milyen eszközrendszerrel rendelkeznek ahhoz, hogy a város további fejlödését aktívan képesek legyenek alakítani.

A most megjelent kőtet az olvasót rögtön továbbgondolásra készteti, összehasonlításra saját városa, vagy a közeli városok példájával és történéseivel, s ezzel ismét ráirányíthatja a figyelmet a hazai városhálózat más elemeinek további kutatására is.

A kötet szerkezete világos, könnyen követhetó, bár az egyes fejezetek sorrendjével vitába lehetne szállni.

A bevezetőben a szerzői kollektíva megfogalmazza a kötet létrejöttének célját: „A könyv keretei között arra kívánunk vállalkozni, hogy feltárjuk a város és a városkörnyék életében a legneuralgikusabb és feszítöbb társadalmi és gazdasági kérdéseket, továbbá a felmerült problémák orvoslására 